Article

\title{
Redesigning Informal Beirut: Shaping the Sustainable Transformation Strategies
}

\author{
Piotr Lorens ${ }^{1}$, Dorota Wojtowicz-Jankowska ${ }^{2, *}$, and Bahaa Bou Kalfouni ${ }^{1}$ \\ ${ }^{1}$ Department of Urban Design and Regional Planning, Gdańsk University of Technology, Poland \\ 2 Department of Environmental Design, Gdańsk University of Technology, Poland \\ *Corresponding author (dowojan@pg.edu.pl)
}

Submitted: 30 July 2021 | Accepted: 3 January 2022 | Published: 23 February 2022

\begin{abstract}
Lebanon is distinguished by its strategic geographical location among the Arab countries. Beirut, as the capital city and the major commercial and cultural centre of the country, is a point of interest for migrants. The region has witnessed many changes since the end of World War II, which have resulted in internal and external conflicts, migrations, the centralization of the country's economy, etc. Furthermore, the city has witnessed many periods of urbanization, destruction, reconstruction, and regeneration, which has contributed to the complex nature of the city's population and a blurring of the boundaries between settlements which are quite different in their natures. As a result, Beirut has become a home to mixed communities and societies of different origins and natures. The extensive inflow of migrants combined with economic crises has contributed to the appearance of informal settlements. They are located in different areas of the city and its surroundings, known as Greater Beirut. These settlements face various challenges, including spatial organization, socioeconomic standing, and environmental concerns. The current situation in Lebanon (resulting from the Covid-19 pandemic combined with the 4th of August 2020 blast in the port of Beirut) makes these challenges even more appalling. Some of the key issues discussed in this article are associated with the origin, current state, and prospects for improving the urban quality of these informal settlements considering their unplanned development and underused potentials. The article includes an inventory and speculates about the best possible strategies derived from three local interventions which are based on published reports. These examples represent rehabilitation and reconstruction activities in different cities in Lebanon. They can be applied to the specific situation of Beirut, given the variety of possible contexts there. The authors' initial intention is to deal with the possible scope of the physical improvement in these settlements which will lead to socioeconomic and environmental development and will also include possible ways of reinventing Beirut's urban structure.
\end{abstract}

\section{Keywords}

Beirut; complex city; immigrants; informal settlements; sustainable development; urban transformation

\section{Issue}

This article is part of the issue "Urbanisation, Crisis, and Resilience: The Multiple Dimensions of Urban Transformation in Beirut, Lebanon" edited by Liliane Buccianti-Barakat (Saint Joseph University) and Markus Hesse (University of Luxembourg).

(C) 2022 by the author(s); licensee Cogitatio (Lisbon, Portugal). This article is licensed under a Creative Commons Attribution 4.0 International License (CC BY).

\section{Introduction}

Lebanon is a very highly urbanized country, as nearly $90 \%$ of its population lives in urban areas and $65 \%$ of those are settled in dense urban agglomerations (UN-Habitat, 2009). Beirut, the capital of commerce and culture in Lebanon, has been widely viewed as an icon and also a symbol of continuous change. Over the decades, Beirut has demonstrated an almost infinite potential for regeneration and urban transition, as a consequence of colonialism and international commerce, internal and external conflicts, and various waves of immigration (Khalaf, 2006). The response to these factors, and particularly to the dynamics of urbanization and the growth of the 
urban population, was in most cases informal, which contributed to the growth of unplanned urban areas. This process resulted in the creation of undersupported informal neighborhoods that can be differentiated by various structural, social, and economic dimensions from the formal part of the city. This phenomenon was especially visible in the second half of the 20th century when the political and socio-economic processes taking place both within Lebanon and in the entire Middle East resulted in increased immigration into the country of large groups of people seeking safety and better economic opportunities. This process resulted in the creation of various types of informal settlements, which differ according to the time period of their origin, social, ethnic, and religious structure, as well as the urban layout. What all of these structures had in common was the need for upgrading, rehabilitating, and reshaping their physical structure, which is considered to be a major issue and is, therefore, discussed in this article. Structural changes resulted in social, economic, and environmental improvements. These changes made these settlements more visible in the structure of the city and changed their reputation: They are no longer perceived as hidden, shameful areas but as places that are not different from the rest of the city of Beirut (Fawaz \& Peillen, 2003).
This article focuses on the challenges to the sustainable transformation of informal settlements in Greater Beirut where these settlements are located. Within the municipal boundaries of the city, the settlements represent a minority, while outside they stand as a majority (see Figure 1). The issues of reshaping their informal urban structure as well as reconnecting them to the city area are of primary interest to the authors. Although upgrading informal settlements is a widely recognized phenomenon and many studies and interventions have been addressed internationally, the strategies picked for safeguarding sustainable transformation are based on local references and not on international ones. Due to its possible social, economic, and physical similarities with the context of the case study, which are discussed in Section 4.3, and since there is a lack of scientific sources on this matter, the authors speculate about the best possible strategies for improving the urban quality of these informal settlements and consider this as a starting point to generate considerable research interest for the future.

The scientific methodology applied in this study relies on literature review and on-site observations. The analysis is based on qualitative rather than quantitative data, as there is not much definite information available in terms of statistics. Also, the field of

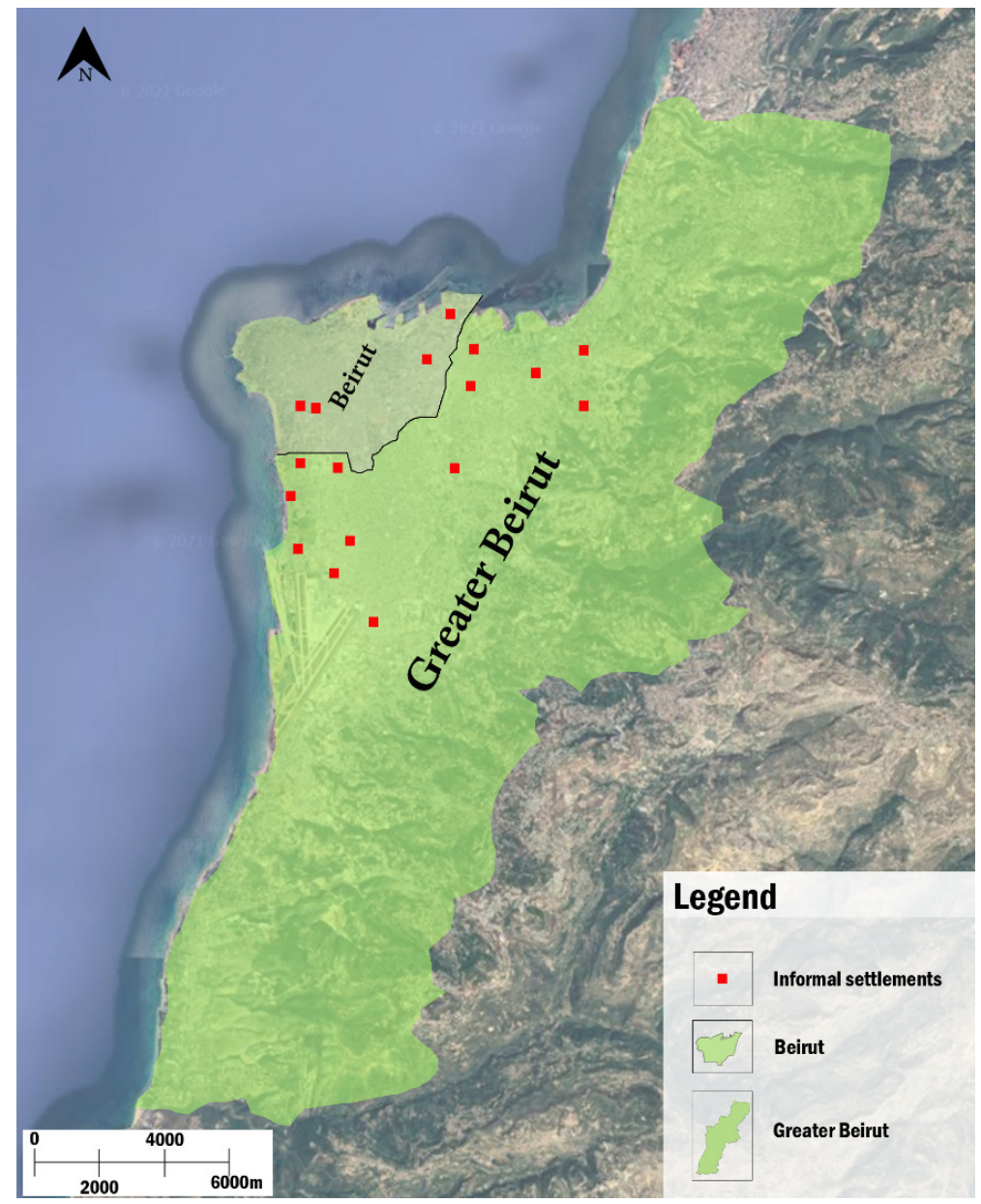

Figure 1. Distribution of informal settlements in the geographical boundaries of Beirut and Greater Beirut. 
research discussed cannot be measured by numbers because the main interest is oriented towards the physical development of informal settlements. The authors relied on presenting programs and strategies based on three well-known cases at the domestic level, aimed at upgrading poor urban areas. The results of these cases were addressed and evaluated based on three criteria (housing, neighborhood, and individual; see Table 2), which were in turn based on published reports, and research conducted on-site by organizing in-person visits to these cases.

The article begins with a discussion of informal urbanism and urban development as an introduction to the topic and highlights what is known and unknown in the context of informality. The next step is a brief presentation of the development of the city through the history, nature, location, and urban forms of informal settlements in Greater Beirut. Next, three transformative projects that have been carried out in other Lebanese cities are discussed and analysed. The last part, which concludes with the main findings and questions about challenges and policies for the application of urban design solutions for informal settlements, allows for the opening of a new field for interdisciplinary research in the future.

\section{Informal Urbanism and Urban Development}

In the early 1970s, the debate about informality began with the advent of the concept of the "informal sector." This occurred as a way to describe the migration of workers to cities in the 1950s and 1960s (Roy \& AlSayyad, 2004), which accompanied the phenomena of industrialization and urbanization. Later on, by the late 1970s, Moser described the informal sector as the "urban poor," a term associated with people living in slums or informal settlements (Moser \& Peake, 1994). At the same time, informal urbanism has been recognized as one of the many existing legitimate processes that contribute to city creation (Boano \& Astolfo, 2016). It is also understood that urban informality can range from informal settlements to street vending and informal transportation (Kamalipour \& Peimani, 2020). In the context of informal settlements, it is estimated that, at present, more than one billion people live in these settlements, and this number is expected to double by 2030 (UN-Habitat, 2006). Regarding informal economy, about two-thirds of the working population of the world are expected to participate in the informal sector activities by 2030 (Neuwirth, 2012). The informal economy includes, among others, activities such as street vending and informal transport; these provide job opportunities, generate income for the urban poor, and bridge formal urban development gaps by negotiating space and visibility in the public sphere. As a result, Roy (2015) described urban informality as a specific mode of production and organization of space. It acts as a hub for managing the pressing challenge of poverty and thus becomes an integral part of providing sustainable livelihoods.
It is crucial to develop a better understanding of how informal and formal urban spaces can be judged based on different forms and systems which can be variously conceived as territorial formation (slum/city), categories of particular economic groups (informal and formal labour), forms of organization (structured/unstructured), and as modes of city manifestations (formal and informal knowledge and practices; Waibel \& McFarlane, 2012). These are located in the Global South where this phenomenon is dominant, taking into account cases such as Kibera (Nairobi, Kenya), Medellin (Colombia), Rocinha (Rio de Janeiro, Brazil), Dharavi (Mumbai, India), Dulce Nombre de Jesús de Petare (Caracas, Venezuela), Khayelitsha (Cape Town, South Africa), Garbage City (Cairo, Egypt), and Al-Sabeel (Jeddah, Saudi Arabia). However, each of them is different, as is the political and social situation in these places. Obtaining knowledge concerning the successful activities in these places is important, but, at the same time, it shows that each of them has a very individual character. This proves that no fixed paradigm of urban change can be derived from the analysis of these cases, although the general lessons for Beirut can be defined.

Based on the existing literature, the authors argue that informal urban development should be regarded as a common practice. In this respect, we present the perspectives of some scholars and researchers dealing with this. For instance, MacFarlane, who has worked extensively with a particular focus on the Global South, has reimagined informality as a formal practice. He pointed out the case of the Mumbai floods in 2005, which highlighted the importance of illegal practices of the state and developers in causing the disaster (Waibel \& McFarlane, 2012). Furthermore, Lombard discussed the phenomenon of "beds in sheds" in the UK that was presented by the media and the government as a cause of immigration. Lombard investigated the case and questioned whether informality is a structure or an agency (Lombard, 2019). Also, Sarmiento and Tilly (2018) discussed the case of immigrants from Latin America in the US, suggesting useful lessons for reinventing urban governance. This was intended to increase our level of understanding concerning the interrelations of informal actors with governance, "understanding how, in the current period of development, displacement, and disinvestment, workers, and settlers have succeeded in winning recognition for their rights of access and possession despite breaching laws and regulations" (Sarmiento \& Tilly, 2018, p. 200). Although the article is devoted to issues that are mainly oriented toward the physical improvement of informal settlements, the authors are aware that this activity occurred due to the existence of effective government actions and policies.

\section{Developing Beirut: An Interplay Between Planned and Informal Interventions}

Understanding the appearance of slums in Beirut and its suburbs requires an overview of the previous 
transformations that progressed in Beirut, which can provide an understanding and a clear image of the fundamental developments that have contributed to the formulation of the city structure from the Ottoman Empire until the present. Particular attention has been directed toward those transformations that have occurred in the second half of the 20th century.

\subsection{Origins of Modern Urban Planning for Beirut}

In 1887, the Ottoman authorities recognized Beirut's role and named it the capital of a new Ottoman wilayat. The new face of the city's urban modernization was established within a wider framework inspired by city planning concepts drawn from the colonial period or the reforms of the Ottoman Empire. Since the end of the 19th century, the Lebanese government has added fresh perspectives to urban transformations in Beirut and its suburbs (Traboulsi, 2012). From the late 18th century until World War I, various projects were established. A well-known and widely recognized example is associated with the development of Burj Square (1878) by the municipality of Beirut, which is considered to be the main meeting place in the city, and the construction of the Ottoman Clock Tower (1898), showing Istanbul time. Another one is the modernization of the "souk" area in Beirut: This was announced in 1915, in addition to the design project of the surrounding areas of the main port of the city based on the concept of an orthogonal grid principle network. At this time, the names of the streets were inspired by the names of the well-known generals, heroes of World War I: Foch, Wigan, and Allenby. The buildings for national institutions like the municipal- ity or the parliament buildings were developed and their architecture was inspired by the new Levantine style. This was established after the region entered the modern era and fell under the influence of Europe in the 19th century, holding the features of a Neo-Mamluk overtone and a Neo-Islamic style. Plans for these developments were also frequently modified. As a result, a new scale of development appeared, which was also spurred by French colonization after the collapse of the Ottoman Empire (Traboulsi, 2012).

In between the world wars, French colonial cities became a field of experimentation for planners. In Beirut, the "Danger Plan" was the first phase of the development of the city centre (1932). This plan was known as Société des Plans Regulateurs des Villes or Danger Frères et Fils. The plan dealt not only with downtown Beirut but also with the Beirut Municipality in its entirety. The project was not fully implemented, except for a few sections of lanes and the circular boulevard (see Figure 2). The urban planning approach advocated by the Danger Plan allowed for the strengthening of the hygienic approach to urban space. This began the debate about the relationship between design and regulations (Hanna, 2020).

Between 1941 and 1943, the French planner Michel Ecochard prepared a master plan aimed at developing Beirut and its suburbs, known as the First Ecochard Plan. The plan introduced the principle of modern planning in the revitalization of the urban structure of the city. The goal was to expand the centre of the city and modernize its outskirts. In cooperation with the state and key actors (see Figure 3) another master plan was developed by the same planner in 1963, which is known

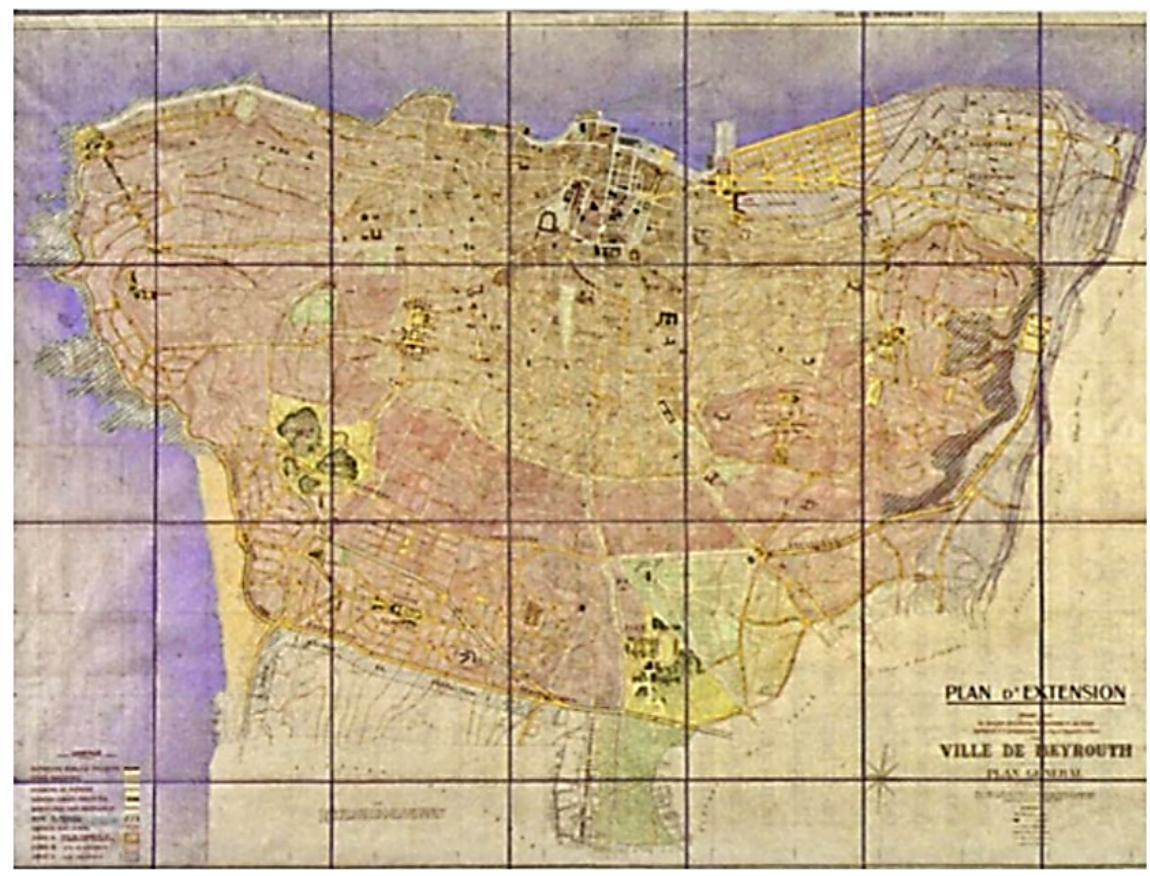

Figure 2. The development, embellishment, and extension plan of Beirut by SPRV, Cabinet Danger Frères et Fils, 1932. Source: Hanna (2020, p. 40). 
as the Second Ecochard Plan (see Figure 4; Rowe \& Sarkis, 1998). These two efforts were never fully implemented due to the pressure applied by the politicalreligious sector in the country, that wished for and succeeded in obtaining "fewer restrictions and more scope for exploitation” (Larkin, 2010, p. 416).

At the beginning of the 1990s the Lebanese government worked on a master plan known by the acronym "Solidere's" which aimed at rebuilding downtown Beirut and linking it to the other parts of the city, bearing in mind all of the issues emerging after the massive destruction caused by the civil war. However, these plans were not completed and partially failed to build a vital urban fabric. These achievements were described as a response to what the private political-religious sector provided, namely the control of urban spaces through only focusing on developing the physical infrastructure without considering the public benefits (Larkin, 2010).

\subsection{The Rise of the Informal Settlements}

Refugee camps are one of the oldest types of informal settlements that appeared in Beirut. These camps were organized for Armenian, Syriac, Palestinian, and Kurdish refugees and located within the municipal limits of the city and its environs. At the same time, in the

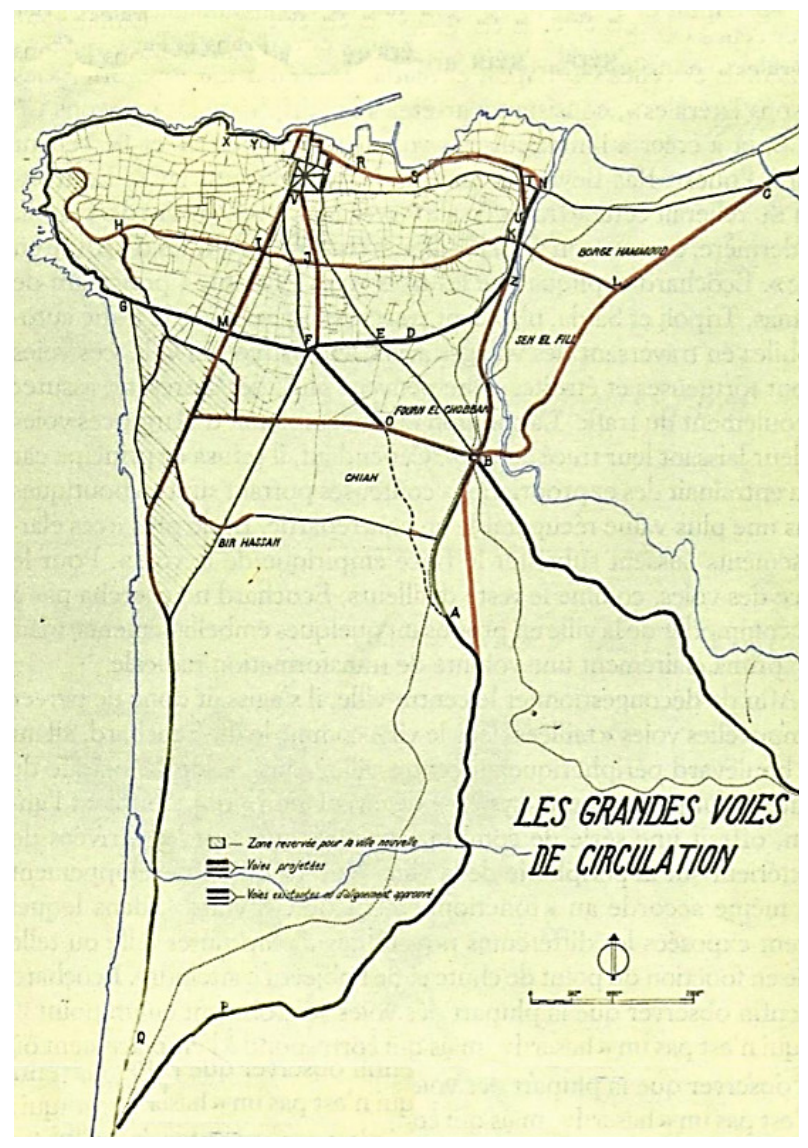

Figure 3. Major traffic lanes and zoning for Beirut and its suburbs by Michel Ecochard, 1943. Source: Hanna (2020, p. 44). context of the country's industrialization and urbanization movement, migrants also arrived from the south of the country and the Bekaa Valley, where destitution and uncertainty increased migration pressure. These informal settlements were mainly concentrated around industrial zones. The outbreak of the civil war, at the beginning of 1975, caused a mass evacuation of the city and the settlement of its suburbs.

The informal housing sector has consistently filled the gaps left by formal state-led planning, focusing primarily on land use and zoning rules that were adopted and applied by the Directorate General of Urban Planning. The lack of affordable housing resulting from low-income housing programs is helping to perpetuate the development of informal housing, a state of affairs which continues to this day. The structure of informal settlements in Beirut varies according to their different patterns, which are identified in terms of their appearance and content (see Section 4.3).

\subsection{The Need for Intervention}

Lebanon had a population of about 6.8 million in 2020 (Central Administration of Statistics, 2021). The current population of its capital, Beirut, includes about 2.2 million inhabitants. At the same time, approximately

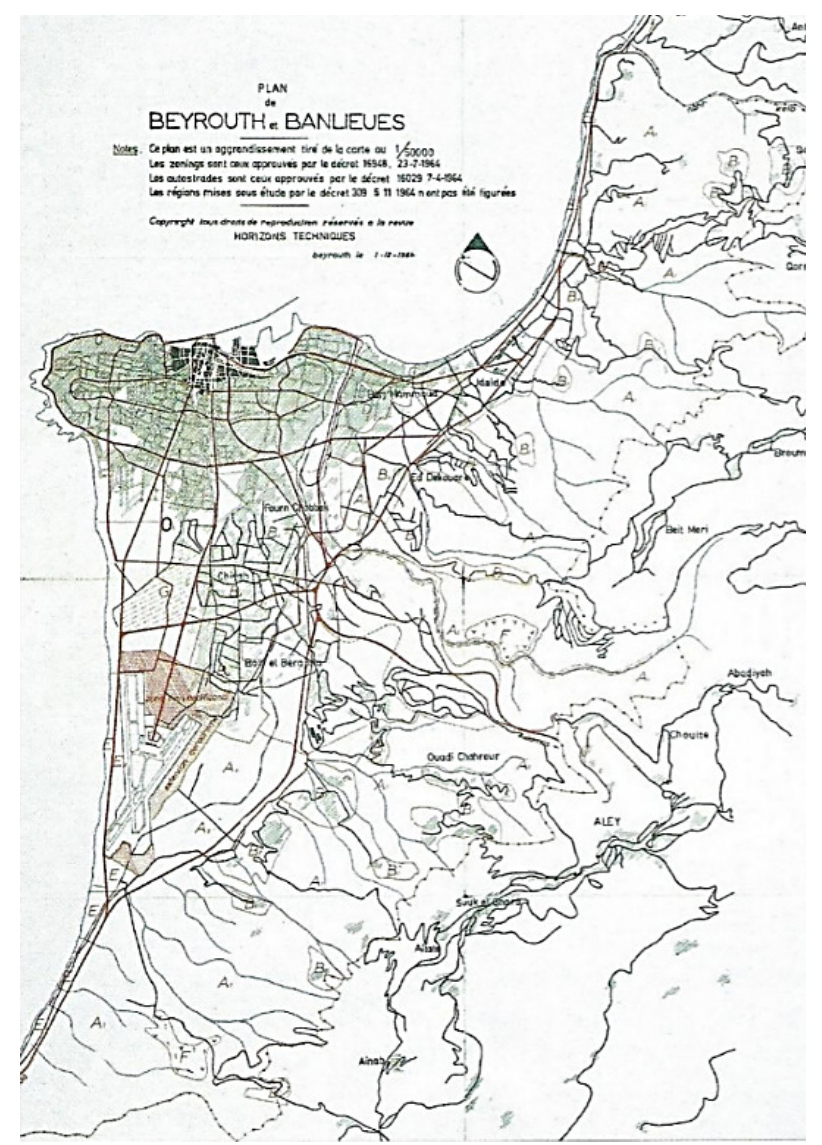

Figure 4. Plan of Beirut and its suburbs by Michel Ecochard, 1963. Source: Hanna (2020, p. 52). 
1.5 million Syrian refugees live in the country, and 202,000 Syrians live in the Beirut metropolitan area. The massive inflow of these refugees was caused by the outbreak of the Syrian war in 2011, which forced the population to migrate and large groups arrived in Lebanon, most of them heading to urban areas, where they believed opportunities and services were available. Refugees are mainly hosted by informal settlements, firstly because they are unable to pay the high rents in the city and secondly because they have relatives living in these settlements. Furthermore, the country has previously received various waves of refugees from Palestine and Iraq as major sources of refugees and other nationalities as minor sources (UNHCR, 2020). The lack of a policy to provide camps for refugees and organize their affairs has led to their random distribution throughout Lebanon and their concentration in urban areas, which has also contributed to a general decline in the quality of services and to the weak infrastructure available in these areas (Forster, 2021). This has come about due to the fact that the Lebanese planning system revolves around a core issue that focuses on addressing urban fragmentation. The poor level of local planning has resulted in an inability to allocate the urban area for new residents. As a result of the civil war (1970-1990), the service systems have visibly deteriorated and their inadequacies have not yet been taken seriously. The absence of strategic planning and the poor scope of the municipal services, in addition to the dominance of private transport as a result of the lack of a public transport service, contributed to the weakening of the urban structure and negatively affected the environment and the health of urban residents (UN-Habitat, 2014).

In addition, Lebanon faced a wide range of challenges in the year of 2020, which threatened the stability and security of the population and led to the deterioration of its urban environments. These crises included a massive explosion in the port of Beirut on the 4th of August 2020, which led to the death of 214 people and the destruction of a large part of the city; a major economic collapse that followed this event and contributed to the rise in product prices and a collapse in the value of the currency; and, finally, the arrival of the Covid-19 pandemic made things even worse (Human Rights Watch, 2021). Furthermore, it should be noted that rapid urbanization has also contributed to the creation of spatial, social, economic, and environmental challenges, forcing residents and refugees to live in crowded urban environments where the standard of living is very low and classified as temporary (Office for the Coordination of Humanitarian Affairs, 2020).

\section{Informal Settlements in Greater Beirut: Origin and Typology}

Poor urban areas may also be found in most cities in Lebanon. Informal settlements are also distributed in the capital city of Beirut and its suburbs, especially in the southern and northeast parts of the city (see Figure 5). Concerning this phenomenon, the term "informal settlements" was used for the first time in the Lebanon Crisis Response Plan, between 2017 and 2020. It referred to poor and illegal urban environments, which were established without the intervention or support of the official Lebanese authorities and in response to the needs of the population for temporary shelter. These settlements were created as a result of humanitarian, economic, and political pressure which called for a rapid solution to the emerging problems of a lack of shelter for the incoming migrants (Government of Lebanon \& UN, 2019). In the subsequent parts of this section, the authors present the characteristics (definitions, demographic typology, urban forms, and location) of the informal settlements in Beirut. However, it should be noted that these characteristics also apply to other cases in Lebanon. The chosen reference projects (Section 5 ) were characterized by the same conditions before their transformation occurred.

\subsection{Definition}

Defining informal settlements in the city of Beirut is a complex matter. however, two definitions have been addressed in this study. The first definition specifies informal settlements as a complex urban area, one which does not have a fixed context due to the many factors related either to its history of establishment, violations beyond building and construction codes, or due to its continuous dynamic transformation and spontaneous growth in response to different circumstances. The authors are adopting this definition for this article.

The second definition describes these settlements as being obviously distinguished from other parts of the city based on their urban morphology and appearance. Often labelled by the media and the general public as "crises of misery," they are well known for the absence of safety and stability, and their residents vary between locals and refugees with low-income levels, in addition to the lack of basic services that are provided in other urban spaces.

\subsection{Demographical Typology}

The only type of classification that can be provided in the selected case study depends on the demographics of these informal settlements. The informal housing complexes in the Beirut metropolitan area may be classified into three different groups (see Figure 5):

- International refugee camp/low-income housing areas for refugees;

- Housing areas for rural-urban migrants;

- Squatter settlements, developed during the civil war.

The first informal settlements that appeared in Beirut in the 1920s were camps occupied by Armenian, Syrian, Kurdish, and Palestinian refugees. These settlements 
were built between 1920 and 1955 in the east of Beirut, specifically in Quarantina and Bourj Hammoud. The growth of these settlements occurred with the arrival of Armenian refugees to the port of Beirut and the establishment of the first well-known Medawar camp (Migliorino, 2008). Currently, these camps are not visible or recognized in the city, as is the case with the Syrian and Palestinian camps, which may be considered dominant within the urban fabric.

After that, rural-to-urban migration (1950-1965) occurred in conjunction with industrialization and urbanization phenomena. Various waves of refugees travelled from the south and north of Lebanon to the city of Beirut and its suburbs, due to poverty and insecurity issues. The migrants benefited from the reality of the urban environment of the city in that period, which provided an opportunity for unlimited urban expansion, especially in the coastal areas and the surrounding hills (Costello, 1977). Therefore, the city faced the development of informal growth, which was not in line with building laws and was followed by land investment.

During the civil war, squatter settlements were established in several parts of the city, where refugees occupied vacant buildings or entire neighborhoods. Also, as a result of the Israeli military attacks in 1978 and 1982, the transformation of the southern suburbs of the capital into massive informal poor settlements occurred which became a home for many Palestinians.

As a result of the outbreak of the Syrian war in 2011, Palestinian refugee camps saw a clear growth in population density. This was caused by the displacement of large groups of Syrians to Lebanon. These movements of people were mainly oriented toward urban areas and opted to populate the informal settlements in the absence of the provision of temporary camps (see Table 1 and Figure 5).

\subsection{Characteristics: Urban Form and Location}

Within this study, the characteristics of the urban form of informal settlements located in Greater Beirut, based on published reports are discussed. These form a part of the urban fabric located within the municipality of Beirut as a minority of the dwellings and spread to the peripheries as the majority. These settlements have physical attributes different from the formal ones in the city, which deserve to be valued and understood, in order to present the appropriate sustainable transformation strategies, aimed at realistic improvement.

Despite the heterogeneity and spontaneity that describe the development of the urban structure of these settlements, some common characteristics may be identified in terms of location and typography, urban infrastructure, and types of buildings:

- Location and Typography: As discussed above, each case shapes its character in terms of form and spatial organization. The urban forms of these settlements may be categorized according to criteria related to their appearance and origins. Their types may be determined according to their typography and location, which include waterfronts, escarpments, and easements.

- Waterfronts: Settlements such as Jnah and Hay Sellom (see Figure 5) are located along the coast of the Mediterranean Sea and partially on the Ghadir River, which flows into the Mediterranean Sea south of Beirut, under Beirut International Airport. This waterbody completely dries up in the summer and is believed to be the most polluted river in Beirut. These types of locations are unsafe due to the high risk of flooding and hurricanes, especially in the winter.

- Escarpments: Settlements located on a large rocky hill, as is the case of Roueissat (see Figure 5). These are subject to strong winds and water penetration from rain during the winter season. The buildings are built around curved streets and connected by long staircases and narrow slopes.

- Easements: Settlements located along with major barriers to urban infrastructure, as is the case of the Chatila refugee camp, bounded by two other settlements. These are located close to the runways of the Rafic Hariri International Airport (e.g., Borj el Brajneh and Hay Sellom; see Figure 5).

- Urban Infrastructure: In general, the urban infrastructure in these informal settlements is characterized by poor structural systems and spatial

Table 1. Summarizing the appearance of the informal settlement.

\begin{tabular}{llll}
\hline Typology of Informal Settlements & Period & Origin & Event \\
\hline 1. Refugees & $\begin{array}{l}1920-1955 ; \\
2011\end{array}$ & $\begin{array}{l}\text { Armenian, Palestinian, Kurds, } \\
\text { and Syrian }\end{array}$ & Exterior war and conflicts \\
2. Rural-Urban Migration & $1950-1960$ & $\begin{array}{l}\text { Mount Lebanon and North } \\
\text { and South Lebanon }\end{array}$ & Urbanization and industrialization \\
& & Lebanese & Civil war and Israeli invasion \\
3. Squatter Settlements & $1970-1990 ;$ & Lin & \\
\hline
\end{tabular}




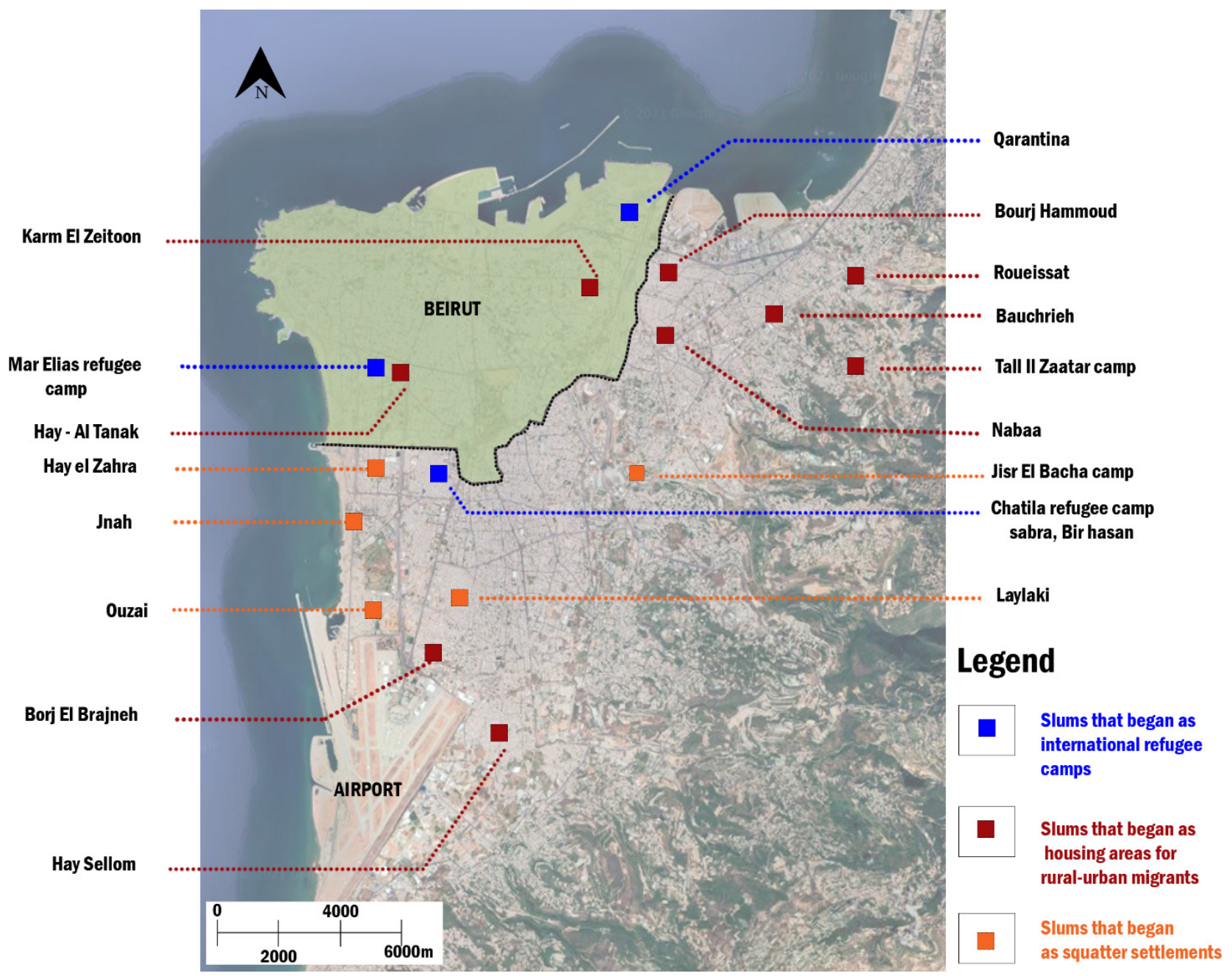

Figure 5. Typology of informal settlements in the metropolitan area of Beirut as a result of their different nature and origin.

arrangements, within which particular buildings are barely separated by narrow paths and sinuous alleys that are often unpaved. Natural lighting and ventilation are not available in sufficient quantity. Public areas and green spaces are also inadequate. The inhabitants travel using motorcycles and cars. Pedestrians flow through the inner barrier lanes, known as "souks," which reflect the vivid image of the spaces, which refers to the commercial activities that take place around these lanes.

- Types of Buildings: Concerning buildings, obvious differences in the type, density, and levels of organization were found among them. The homes in these informal settlements vary between small family houses, small buildings, multi-story buildings, and shacks. The scale and features of the buildings indicate their informal nature and distinguish them from other physical urban environments in the city that are considered to be formal. Services and their uses vary in these settlements, which may be characterized in terms of legal, illegal, or completely absent, in particular water and electricity networks.
The living spaces of the dwellers vary according to the density of the population in the settlement. These are characterized by the accumulation of small rooms that are spontaneously built in both directions: horizontally and vertically. Additionally, another incremental growth of additional spaces is visible, which is a small-scale additional living space, attached to the main structure, such as terraces and balconies. The quality of construction materials ranges from reinforced concrete, concrete blocks, steel, and metal corrugated sheets. The material varies with geographical location, culture, economy, and density. These practices, which were based on the needs of the inhabitants in the absence of professional planning, contributed to the appearance of chaos and the disorganized structure in terms of forms and accessibility.

\section{Urban Transformations: Reference Projects at the Domestic Level}

This section discusses three interventions (poor urban area transformation) that have occurred on a large scale, particularly in Northern and Southern Lebanon (upgrading Palestinian refugees camps, reconstruction of the 
Nahr El-Bared refugee camp, and the rehabilitation of the old Saida residential neighborhood and Haddadine Tripoli). These projects were selected based on proximate conditions and similarities in the characteristics and nature of the ones in Beirut (Section 4). In this sense, certain solutions and initiatives to transform these settlements should be taken carefully to respond to these particular circumstances, which makes these initiatives different from the international projects presented in Section 2.

Furthermore, these interventions are considered to be applicable references and resources, which have proven to be a real success in terms of developing refugee camps and poor urban areas, thus creating potential at the social, economic, and environmental levels. Therefore, they are chosen based on their applicability and not on a systematic analysis of informality (this should be performed in subsequent research). These implemented changes respond to the special needs and challenges that arise from different circumstances and origins.

\subsection{Upgrading Activities for Palestinian Refugee Camps in Lebanon: UN Relief and Works Agency}

This project aims to improve the conditions of Palestinian camps in Lebanon and to support their residents, especially in terms of housing, by providing decent and safe housing to the vulnerable population. The interventions implemented by the organization includes three camps located in the Beirut metropolitan area: Burj Al-Barajneh, Shatila, and Mar Elias. Many of these upgrades are not visible as the UN Relief and Works Agency faced funding problems, which led to a reduction of their activities to a minimum. The operations were based on building transformations which may be addressed as follows: restoration, adaptation, refurbishment, and extension.

The elaborate strategies developed have achieved many immediate results. For instance, renovating or constructing sanitation facilities has improved household hygiene conditions. Improvements in roof quality, window flashing, or guttering in buildings have reduced the negative impact of the dwelling space on the health of the dwellers (reducing humidity, water droplets). Improvements in home partitions, especially for crowded homes, have provided more space and more comfort for families. The repair of the water and electricity networks has allowed the required amount of water to be delivered to homes. Restructuring the electricity network provided the energy required for the neighborhood, which contributed to improving the level of safety at night. The work required to provide internal ventilation and a lighting system was carried out through the provision of appropriate windows that ensure comfort and positively affect user behaviour. Repairing the main entrances has improved security and provided privacy to the residents.

The various strategies applied have also had longterm effects, such as strengthening the concept of mutual support between communities, which leads to the development of a sense of belonging and unity. They have also encouraged residents to distribute their income within the sectors that give them back benefits, strengthen businesses at the local level, and invest in education and health care services. These activities have led to a reduction in the sources of stress associated with urban environmental degradation and the strengthening of ties within the neighborhood through the exchange of services and the sharing of spaces.

The interventions succeeded in providing the potential benefits for residents. These capitalized on the presence of large numbers of families in this urban environment. Decision-makers addressed the need to construct new buildings in response to community needs; this accompanied the adoption of the principle of the reconstruction and maintenance of existing structures. To date, 504 buildings have been refitted in nine different camps and informal settlements for Palestinian refugees in the country (Habitat For Humanity Great Britain, 2016).

\subsection{Reconstruction of the Nahr El-Bared Refugee Camp}

The camp is located in the north of Lebanon, near the Mediterranean Sea. The reconstruction operation of the camp occurred in 2011 after $95 \%$ of it was destroyed between May and September 2007 due to confrontations between a rebel group called Fatah al-Islam and the Lebanese Armed Forces. During these conflicts, homes, commercial services, mosques, local health clinics, schools, and infrastructure networks were severely damaged or destroyed (see Figure 6). Approximately 26,000 Palestinian refugees have been forced to leave their homes. The role of the community was recognized, as they actively participated in the design process, which took place in a series of eight construction phases.

The social and urban fabrics were considered to be essential elements in this project at each stage in order to achieve continuity and satisfaction from start to finish. The strategies developed worked to change the infrastructure network of the camp, and provide innovative and efficient services to individuals and the neighborhood as a cohesive technical structure (running water networks, potable water, and sanitation). The housing units were improved as compared to their previous configurations and this led to the provision of adequate natural ventilation. More public spaces were provided around the buildings and an architectural system consisting of extendable structures was introduced based on the needs of residents. These structures were built in response to building codes and area requirements (maximum of four-story buildings; Frearson, 2013). The reconstruction of public buildings in the same neighborhood was based on the pattern of the original structure, although improvements were made in the common areas and infrastructure (see Figure 6).

The local community took an active role in decision making and this was implemented through discussion 

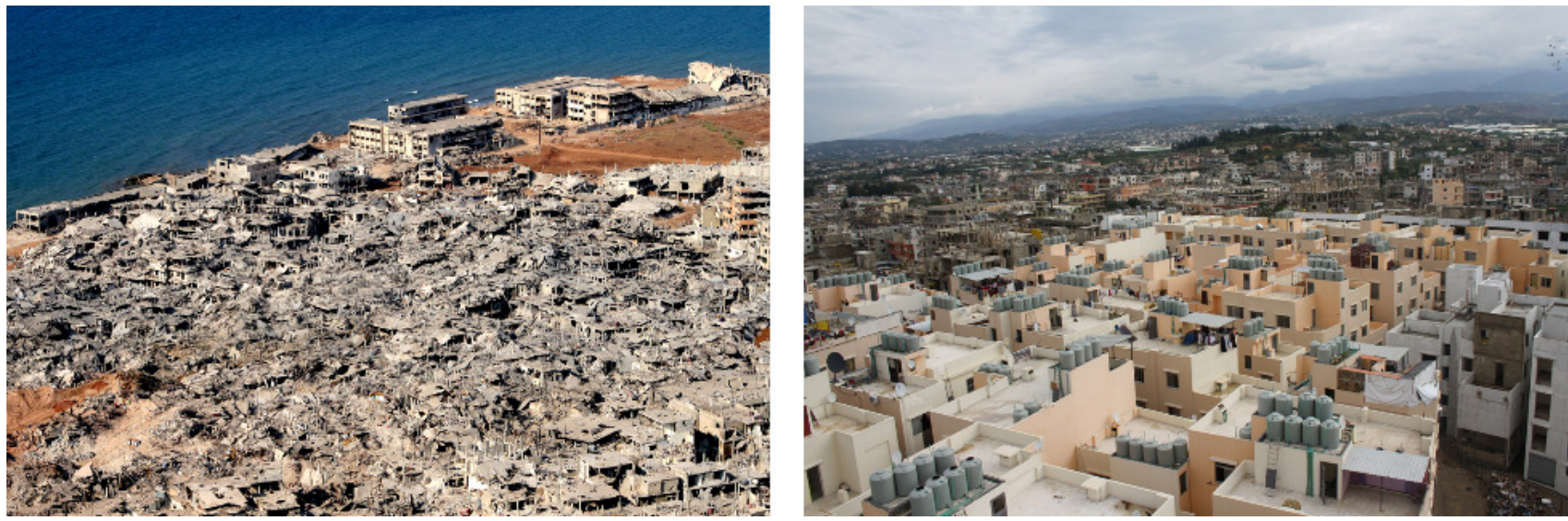

Figure 6. Nahr El-Bared refugee camp: Before and after reconstruction. Source: Courtesy of Aga Khan Awards for Architects.

and interaction in public places. This was the factor that gave the transformation operation a sophisticated and modern pattern (Aga Khan Development Network, 2011). Work began with practical coordination and communication to avoid any controversy; this was undertaken through regular meetings with the Reconstruction Committee and community representatives. An important part of this cooperation was the fostering of new working relationships with the Lebanese community, the government, and various local and international stakeholders.

As presented above, the settlement was redesigned from scratch and went through a reconstruction operation without upgrading it, since it was completely destroyed. However, the elaborate strategies used produced comprehensive results, which contributed to the restoration of the camp. Based on this outcome, similar operations could play a crucial role in the future and become the backbone of a movement to inspire transformation programs for informal settlements or poor urban structures in the case of Beirut, in full coordination and agreement with the community and the government.

\subsection{Rehabilitation of the Old Saida Residential Neighborhood and Haddadine Tripoli}

The projects were led by two international organizations: UN-Habitat and UNICEF. The neighborhoods are located in two different parts of the country, one in the north and one in the south. Both accommodate locals and refugees living in inappropriate conditions, with a low income, lack of opportunities, and a lack of basic services. These factors have contributed to the spread of the poverty crisis in these urban spaces. These two projects have proved that upgrade activity results in gentrification. Furthermore, innovative concepts have been used in these interventions, which include focusing on a parallel approach: improving the physical structure and well-being of residents, while at the same time organizing activities and workshops aimed at raising users' awareness about this improvement (UN-Habitat, 2020), which is intended to directly assist in alleviating poor housing conditions for vulnerable families, locals, and refugees.

The team in charge conducted a detailed field survey in order to identify the most damaged buildings and housing units that required immediate intervention. The implementation process included the careful renovation of the residents' homes, improving sanitation, and the provision of drinking water. This resulted in the

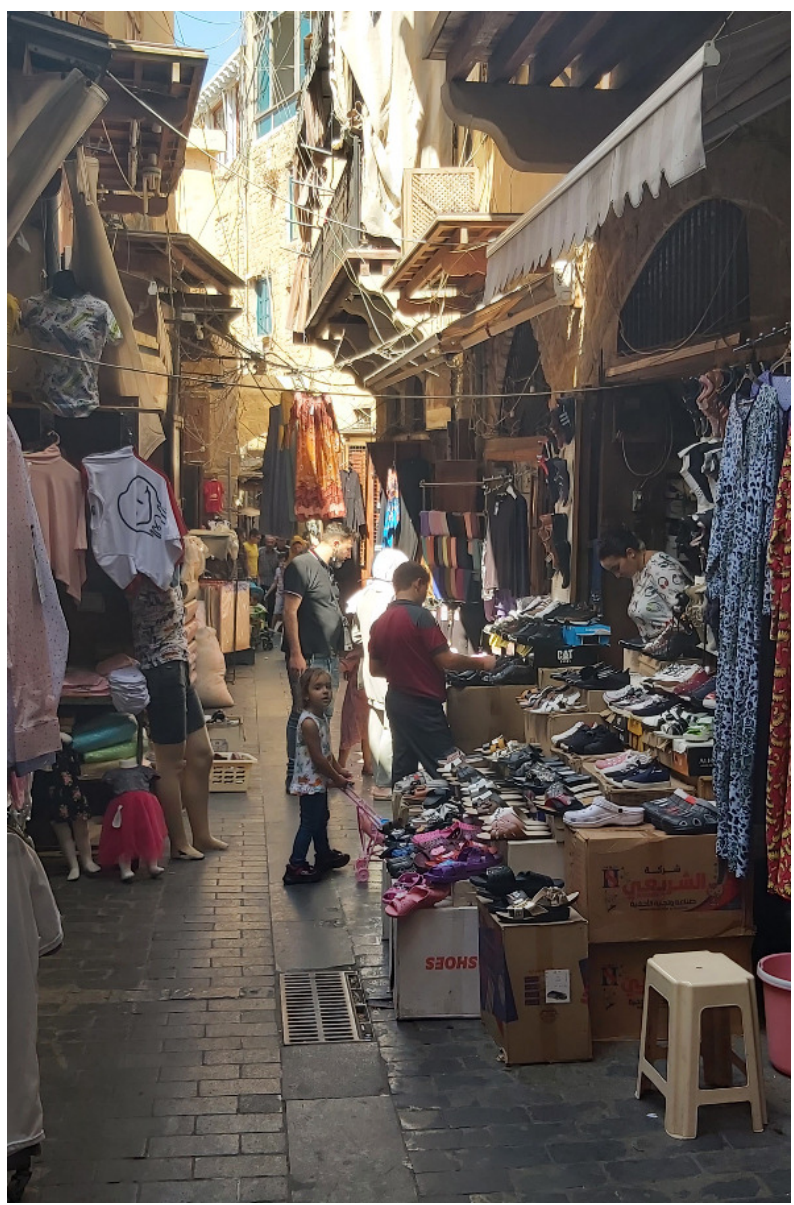

Figure 7. Souks in the old Saida neighborhood: Social interaction between vendors and different age groups of buyers. 
protection of the dignity of their users and also in the development of respect for the historical image of the neighbourhod. These two concepts have contributed to creating a sense of ownership among residents toward these neighborhoods after their marginalization for a long period. In addition to preserving historic buildings in these neighborhoods and protecting them from physical damage or destruction, the team responsible worked to develop the local alleys. These proved capable of increasing accessibility in the entire neighborhood by renovating old souks and saving their historical pattern, and also securing livelihood opportunities in the local markets (see Figure 7). An important part of this activity was to strengthen the critical role of cultural heritage by training residents in different neighborhoods. This was brought about by focusing on cooperation with both municipalities to increase the sustainability awareness program of the project and to encourage youth to participate in restoration work (UN-Habitat, 2019).

UN-Habitat is using its previous experience in both cases to identify and renovate the damaged structure in the historic Beirut neighborhoods, as a result of the port explosion. In addition to humanitarian relief, the main objective was to prevent any inevitable displacement of people, which could eventually change the original social fabric of the city or leave it deserted (UN-Habitat, 2020). It may be concluded that the success of the interventions was expected and its impact on the neighborhood was confirmed.

\section{Discussion and Conclusions}

The elaborate strategies followed in the interventions presented above succeeded in meeting both the needs of the inhabitants and the physical environment. The physical transformation of the spaces relied on a combination of urban renewal and rehabilitation concepts that were achieved through the completion of repair, renovation, extension, and adaptation. The interventions brought about a new perspective towards transforming informal settlements in Lebanon. Key actors, such as stakeholders, have succeeded in understanding the role of urban design and architecture in solving complex problems.

A factor that contributed to the creation of a sense of ownership and also to the strengthening of a sense of solidarity between communities was associated with the development of a bottom-up approach that started with inviting residents to participate in the design process and making decisions. Advanced studies, in collaboration with various experts, have allowed for the development of site-specific and community-accepted transformation concepts.

It appears that the physical improvement that resulted in the adoption of effective urban design and architecture tools have contributed to the creation of the mature character of these neighborhoods. This has led to the creation of dynamic urban borders and a healthy environment. This phenomenon is obvious in the case of the second project (Nahr El-Bared refugee camp, Section 5.2). For example, the diverse uses of the spaces around footpaths in narrow alleys to create dynamic social activities, particularly in the commercial sector, has allowed for the modernization and development of local knowledge. These concepts provide decent areas for various activities that were promoted as offering a set of advantages and opportunities, thereby making neighborhoods more popular and safe for tourism promotion. This is most evident in the case of the residential neighborhoods of old Saida.

The authors have analysed the results of the local intervention from their perspective and separated these outcomes into three groups: housing outcomes (HO), neighborhood outcomes (NO), and individual outcomes (IO). Each group concerns different measurements that concentrate on the physical transformation and its effect on users and their relationship with the city. For instance, the criteria addressed in $\mathrm{HO}$ are aimed at evaluating the results from the housing sector level (assets, infrastructure materials, housing site investments, location, household size). The criteria in NO are intended to evaluate the results from the overall neighborhood level (transport, infrastructure service, safety, mobility, integration into the formal city). The criteria in 10 are intended to evaluate the outcomes concerning individuals living in these settlements (income, labour market, human capital, health, well-being; see Table 2).

Within this article, the authors have suggested specific aspects that should be taken into account for future interventions in dealing with the settlements presented in Beirut and its suburbs. These recommendations are summarized as promoting further training and the sharing of professional experience in order to empower organizational and technological capabilities. It is crucial to focus on strengthening administrative and technical initiatives, in terms of resources and equipment, which allow for the development of high-quality urban environments. It is also important to ensure financial sustainability by providing and promoting services that are responsive to local needs. Not without significance is the development of humanitarian capabilities, which will contribute to finding a solution to various crises and also lead to increased efficiency in the processes of establishing and implementing development projects. Operating with transparency and objectivity results in the participation of efficient stakeholders through building bonds and strengthening relationships for further development, the promotion of sustainable mobility, and the creation of a healthier environment and community.

It may also be concluded that it is crucial to apply urban design solutions to informal settlements compatible with vital social and economic factors. These solutions could be widely applied in the case of Beirut. There are still questions revolving around the challenges of applying the suggested solutions. Are these issues a part of urban policy related to informal settlements? Should the policy on upgrading informal settlements 
Table 2. Evaluation of the outcome of local intervention based on different measurements.

\begin{tabular}{|c|c|c|c|c|c|}
\hline \multicolumn{6}{|c|}{ Intervention Outcomes (HO, NO, IO) } \\
\hline CRITERIA & $\mathrm{HO}$ & CRITERIA & NO & CRITERIA & 10 \\
\hline Assets & $\begin{array}{l}\text { Value of dwelling } \\
\text { (condition and size) }\end{array}$ & Transport & $\begin{array}{l}\text { Availability of } \\
\text { transport links } \\
\text { between the } \\
\text { settlement and } \\
\text { other parts of the } \\
\text { city }\end{array}$ & Income & Household income \\
\hline $\begin{array}{l}\text { Infrastructure } \\
\text { Material }\end{array}$ & $\begin{array}{l}\text { Access to safe water, } \\
\text { sanitation, electricity } \\
\text { connection, material, } \\
\text { and area of the } \\
\text { dwelling }\end{array}$ & $\begin{array}{l}\text { Infrastructure } \\
\text { Service }\end{array}$ & $\begin{array}{l}\text { Availability of street } \\
\text { pavement lighting, } \\
\text { garbage collection, } \\
\text { health centres, } \\
\text { clinics, police } \\
\text { stations, public } \\
\text { spaces, green areas, } \\
\text { and public schools }\end{array}$ & $\begin{array}{l}\text { Labour } \\
\text { Market }\end{array}$ & $\begin{array}{l}\text { Number of } \\
\text { households working } \\
\text { in the } \\
\text { formal/informal } \\
\text { sector }\end{array}$ \\
\hline $\begin{array}{l}\text { Housing Site } \\
\text { Investments }\end{array}$ & $\begin{array}{l}\text { Sources of funds for } \\
\text { the project }\end{array}$ & Safety & $\begin{array}{l}\text { Security in the } \\
\text { neighborhood, child } \\
\text { safety, level of crime, } \\
\text { robberies, and } \\
\text { violence }\end{array}$ & $\begin{array}{l}\text { Human } \\
\text { Capital }\end{array}$ & $\begin{array}{l}\text { Higher education } \\
\text { and school } \\
\text { enrollment }\end{array}$ \\
\hline Location & $\begin{array}{l}\text { Vulnerability to } \\
\text { natural disasters }\end{array}$ & Mobility & $\begin{array}{l}\text { Safety of pedestrians } \\
\text { (young and old) and } \\
\text { inner transportation } \\
\text { (cars, bicycles, } \\
\text { motorcycles) }\end{array}$ & Health & $\begin{array}{l}\text { Diseases and } \\
\text { infection, cognitive } \\
\text { development }\end{array}$ \\
\hline $\begin{array}{l}\text { Household } \\
\text { Size }\end{array}$ & $\begin{array}{l}\text { Providing or } \\
\text { expanding living } \\
\text { spaces according to } \\
\text { the number of } \\
\text { dwellers in every } \\
\text { apartment }\end{array}$ & $\begin{array}{l}\text { Integration } \\
\text { Into the } \\
\text { Formal City }\end{array}$ & $\begin{array}{l}\text { Levels of services } \\
\text { available in the } \\
\text { settlements } \\
\text { demanded by } \\
\text { neighborhood }\end{array}$ & Well-Being & Level of satisfaction \\
\hline
\end{tabular}

be complemented? What are the new dimensions that should be associated with urban design? The last question is based on the debates presented in Section 2: Does viewing informality as an acceptable practice bring about a better understanding of the roles of diverse actors in producing and responding to it?

In addition to these conclusions, the analysis of the case of Beirut can be used to add to the discussions concerning the issues associated with the concept of "clientelism," which provides benefits and services to the poor in exchange for political support. This is based on the relationship between informal politics, planning, and informal urban growth. This concept may also attract the attention of researchers in the future. Based on its realities, the question arises as to whether informalityin the case of Lebanon-is a product of political parties and whether the policy of developing and transforming the informal settlements is based on increasing the influence of these parties in certain geograph- ical areas and strengthening the bonds of patronage and subordination. In light of this concept, the informal settlements appeared to be a source of pressure used by these parties to impose their influence on the state (territorial management). This was demonstrated during the Covid-19 pandemic when the role of the parties in securing support (i.e., ensuring hospitals and isolation centers) was proven. This analysis also contributes to the discussion concerning the outcomes of the weakness of the state in providing services to vulnerable communities. This leads us to question the manner in which the concepts of clientelism and informal urban growth are related. Also, further research is required to determine the extent to which the political parties are involved in shaping informality and the extent to which they benefit from this involvement. And, finally, how should the practice of urban design respond to these matters? These issues and questions may become interesting topics for further research. 


\section{Acknowledgments}

The authors are grateful for the exceptionally valuable comments from the reviewers and editors.

\section{Conflict of Interests}

The authors declare no conflict of interests.

\section{References}

Aga Khan Development Network. (2011). Reconstruction of Nahr el-Bared refugee camp. https://www. akdn.org/architecture/project/reconstruction-nahrel-bared-refugee-camp

Boano, C., \& Astolfo, G. (2016). Informal urbanism, city building processes and design responsibility. I Quaderni di Urbanistica Tre, 4(8), 51-60. https:// discovery.ucl.ac.uk/id/eprint/1482163

Central Administration of Statistics. (2021). Home. http://www.cas.gov.lb

Costello, V. F. (1977). Urbanization in the Middle East. Cambridge University Press.

Fawaz, M., \& Peillen, I. (2003). Urban slums reports: The case of Beirut, Lebanon. University College London. https://www.ucl.ac.uk/dpu-projects/Global_ Report/pdfs/Beirut.pdf

Forster, R. (2021). No city is the same: Livelihood opportunities among self-settled Syrian refugees in Beirut, Tripoli and Tyre. CMI-Chr. Michelsen Institute. https://www.cmi.no/publications/7709-no-city-isthe-same-livelihood-opportunities-among-selfsettled-syrian-refugees-in-beirut

Frearson, A. (2013, May 2). Reconstruction of Nahr elBared Refugee Camp. Dezeen. https://www.dezeen. com/2013/05/02/reconstruction-of-nahr-el-baredrefugee-camp

Government of Lebanon, \& United Nations. (2019). Lebanon crisis: Response plan 2017-2020 (2019 update). https://reliefweb.int/sites/reliefweb.int/ files/resources/67780.pdf

Habitat For Humanity Great Britain. (2016). Upgrading Palestinian refugees camps in Lebanon (slum rehabilitation). https://www.habitatforhumanity.org.uk/ blog/2016/09/upgrading-palestinian-refugeescamps-lebanon-slum-rehabilitation

Hanna, N. (2020). Construction, destruction, reconstruction: Historique des plans et projets pour le centreville de Beyrouth [History of plans and projects for the city center of Beirut] [Unpublished Master's thesis]. Université Libre de Bruxelles. https://issuu.com/ laetitiahanna/docs/20200910_tfe_avec_postface

Human Rights Watch. (2021). Lebanon: Events of 2020. https://www.hrw.org/world-report/2021/countrychapters/lebanon

Kamalipour, H., \& Peimani, N. (2020). Informal urbanism in the state of uncertainty: Forms of informality and urban health emergencies. Urban Design Inter- national, 26(2), 122-134. https://doi.org/10.1057/ s41289-020-00145-3

Khalaf, S. (2006). Heart of Beirut: Reclaiming the Bourj. Saqi Books.

Larkin, C. (2010). Remaking Beirut: Contesting memory, space, and the urban imaginary of Lebanese youth. City \& Community, 9(4), 414-442. https://doi. org/10.1111/j.1540-6040.2010.01346.x

Lombard, M. (2019). Informality as structure or agency? Exploring shed housing in the UK as informal practice. International Journal of Urban and Regional Research, 43(3), 569-575. https://doi.org/10.1111/ 1468-2427.12705

Migliorino, N. (2008). (Re)constructing Armenia in Lebanon and Syria: Ethno-cultural diversity and the state in the aftermath of a refugee crisis. Berghahn Books.

Moser, C. N., \& Peake, L. (1994). Seeing the invisible: Women, gender and urban development. Centre for Urban and Community Studies, University of Toronto. https://tspace.library.utoronto.ca/bitstream/1807/ 91927/1/Seeing_the_Invisible_TSpace.pdf

Neuwirth, R. (2012). Stealth of nations: The global rise of the informal economy. Anchor.

Office for the Coordination of Humanitarian Affairs. (2020). Covid-19 emergency appeal: Lebanon. https://reliefweb.int/sites/reliefweb.int/files/ resources/LEA_JulyUpdate_FINAL.pdf

Rowe, P. G., \& Sarkis, H. (1998). Projecting Beirut: Episodes in the construction and reconstruction of a modern city. Prestel.

Roy, A. (2015). Urban informality: The production and regulation of space. In J. D. Wright (Ed.), International encyclopedia of the social \& behavioral sciences (pp. 818-822). Elsevier.

Roy, A., \& AlSayyad, N. (Eds.). (2004). Urban informality: Transnational perspectives from the Middle East, Latin America, and South Asia. Lexington Books.

Sarmiento, H., \& Tilly, C. (2018). Governance lessons from urban informality. Politics and Governance, 6(1), 199-202. https://doi.org/10.17645/pag.v6i1.1169

Traboulsi, F. (2012). A history of modern Lebanon (2nd ed.). Pluto Press.

UN-Habitat. (2006). The state of the world's cities 2006/7. The millennium development goals and urban sustainability: 30 years of shaping the habitat agenda. Earthscan. https://unhabitat.org/sites/default/ files/download-manager-files/State\%20of\%20the \%20World\%E2\%80\%99s\%20Cities\%2020062007.pdf

UN-Habitat. (2009). Country programme document 2008-2009: Lebanon. https://unhabitat.org/sites/ default/files/2014/07/UN-Habitat-CountryProgramme-Document-2008-2009-Lebanon.pdf

UN-Habitat. (2014). Lebanon urban issues. https:// unhabitat.org/lebanon

UN-Habitat. (2019). Old Saida: Neighbourhood profile. Saida, South Lebanon. https://unhabitat.org/sites/ default/files/2020/11/un-habitat-unicef_old_saida_ 
neighbourhood_profile.pdf

UN-Habitat. (2020). Preserving historic Lebanese homes through heritage conservation and urban renewal. https://unhabitat.org/preserving-historic-lebanesehomes-through-heritage-conservation-and-urbanrenewal
UNHCR. (2020). 2021 planning summary. Operation: Lebanon. https://reporting.unhcr.org/sites/default/ files/pdfsummaries/GA2021-Lebanon-eng.pdf

Waibel, M., \& McFarlane, C. (2012). Urban Informalities: Reflections on the formal and informal. Routledge.

\section{About the Authors}

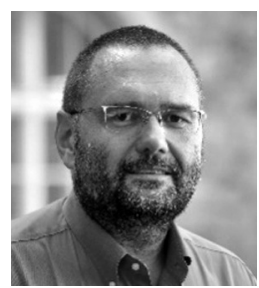

Piotr Lorens, PhD, DSc, is an urban planner, Gdańsk City architect (since 2021), full professor in urban design and development (since 2016), and head of the Department of Urban Design and Regional Planning at the Faculty of Architecture, Gdańsk University of Technology (since 2007). His research interests include urban planning and regeneration processes, with a special focus on waterfront areas and public spaces.

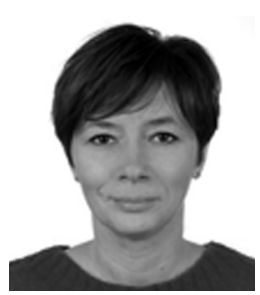

Dorota Wojtowicz-Jankowska, PhD, DSc, is an architect and professor at the Gdańsk University of Technology working in the Department of Sustainable Design Architecture at the Faculty of Architecture. Her field of scientific interests are connected with urban transformation, e.g., revitalization of degraded areas, creating public spaces, and landscape architecture. She is involved in didactic activities, where she emphasizes the obligation of architects towards the community for which they shape the space.

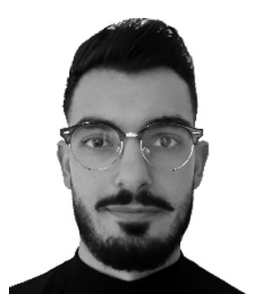

Bahaa Bou Kalfouni is an architect, urban designer, and doctoral student at the Department of Urban Design and Regional Planning of Gdańsk University of Technology. His research interests include urban transformation and revitalization, with a special focus on degraded areas (slums and informal settlements). Currently, he works on the case of Beirut, Lebanon, focusing on developing sustainable transformation strategies (bottom-up approaches) for informal settlements in cooperation with local communities and authorities. 